\section{Management of Fertilizers and Water for Ornamental Plants in Urban Landscapes: Current Practices and Impacts on Water Resources in Florida}

\author{
Amy L. Shober ${ }^{1}$, Geoffrey C. Denny ${ }^{2,4}$, and Timothy K. Broschat ${ }^{3}$
}

ADDITIONAL INDEX WORDs. best management practices, nutrients, irrigation

SuMMARY. Rapid population growth and urbanization in Florida have increased the number of urban landscapes that receive fertilization and irrigation. Consequently, maintenance of these landscapes may contribute to water shortages and water quality degradation. This article 1) describes the current fertilizer and water use practices that are used by homeowners and landscape professionals; 2) summarizes the research related to nutrient and water use by landscape plants; and 3 ) provides an overview of the critical issues that should be considered as we evaluate the need for improved management of water and nutrients in urban landscapes.

$\mathrm{W}$ ater and chemical use in urbanized areas is significantly influenced by the desire for beautiful landscapes (Haley et al., 2007; Hipp et al., 1993). Improper irrigation and fertilization of ornamentals in urban landscapes may result in water quality degradation (e.g., eutrophication). Various best management practices (BMPs) have been developed and implemented in an effort to reduce environmental pollution and water consumption associated with urban landscapes. Recommended BMPs include fertilization practices, irrigation strategies, alternative landscape plant species (e.g., native ornamentals instead of turfgrass, plants requiring low water input), and structural features (e.g., swales, green roofs, rain gardens). However, the impacts of these BMPs on water consumption in and nutrient losses from urban landscapes have not been fully evaluated. Consequently, our objectives in this article are to 1) describe the current fertilizer and water use practices that are used by homeowners and landscape

This work was supported by the Florida Agricultural Experiment Station and the Southwest Florida Water Management District.

Trade names and products are mentioned without endorsement or discrimination.

${ }^{1}$ University of Florida, Soil and Water Science, 14625 CR 672, Wimauma, FL 33511

${ }^{2}$ University of Florida, Environmental Horticulture Department

${ }^{3}$ University of Florida, IFAS, Fort Lauderdale REC, 3205 College Avenue, Davie, FL 33314

${ }^{4}$ Corresponding author. E-mail: alshober@ufl.edu. professionals; 2) summarize the research related to nutrient and water use by landscape plants; and 3 ) provide an overview of the critical issues that should be considered as we evaluate the need for improved management of water and nutrients in urban landscapes.

\section{Nutrient and water management practices for landscape ornamentals}

The nutrient and water management practices of homeowners and commercial landscape professionals are difficult to quantify. Most of the available information about water and nutrient use on landscape ornamentals plants has been gathered using surveys. It is important to understand that results from surveys conducted outside of Florida may not represent fertilizer and water use by Florida homeowners and landscape professionals.

Homeowners. A survey of Florida residents from 23 counties (who had not received information or training related to landscape management practices from the Florida Cooperative Extension Service) was conducted in 1995 to determine the landscape management practices of Florida consumers. Results of the survey found $20 \%$ of residents were not fertilizing ornamental landscape plants. Among residents who did fertilize landscape plants, $60 \%$ of respondents were applying fertilizers two to four times per year (Knox et al., 1995). Similarly, a survey of the landscape management practices followed by Georgia homeowners indicated that $76 \%$ of respondents maintained and applied fertilizers to their own landscapes. Among the respondents, $66 \%$ indicated that they fertilized shrubs and trees and $75 \%$ indicated that they fertilized flowers (Varlamoff et al., 2001). In contrast, a survey of residents of the Neuse River Basin, NC, indicated that most homeowners did not fertilize ornamental landscape plants (D.L. Osmond, personal communication).

With respect to water management in Florida landscapes (ornamentals + turf), a survey conducted in central Florida found that, on average, $64 \%$ of the total household water was used for irrigation purposes, which equated to two to three times the amount of irrigation required by the plants (Haley et al., 2007). Research suggests that the overirrigation of landscapes may be directly influenced by the type of irrigation system being used by homeowners. For example, Florida homeowners who use automatic timers for irrigation currently apply $47 \%$ more water for landscape irrigation than homeowners without automatic irrigation systems (Mayer et al., 1999). Similarly, the volume of water used by residents of Cary, NC, who used fixed irrigation systems was about double that of

\begin{tabular}{llll}
\hline $\begin{array}{l}\text { Units } \\
\begin{array}{l}\text { To convert U.S. to SI, } \\
\text { multiply by }\end{array}\end{array}$ & U.S. unit & SI unit & $\begin{array}{l}\text { To convert SI to U.S., } \\
\text { multiply by }\end{array}$ \\
\hline 0.4047 & $\mathrm{acre}(\mathrm{s})$ & $\mathrm{ha}$ & $2.471 \mathrm{l}$ \\
0.3048 & $\mathrm{ft}$ & $\mathrm{m}$ & 3.2808 \\
0.0929 & $\mathrm{ft}^{2}$ & $\mathrm{~m}^{2}$ & 10.7639 \\
3.7854 & $\mathrm{gal}$ & $\mathrm{L}$ & 0.2642 \\
2.54 & inch $(\mathrm{es})$ & $\mathrm{cm}$ & 0.3937 \\
48.8243 & $\mathrm{lb} / \mathrm{l} 000 \mathrm{ft}^{2}$ & $\mathrm{~kg} \cdot \mathrm{ha}^{-1}$ & 0.0205 \\
1.1209 & $\mathrm{lb} / \mathrm{acre}^{-1}$ & $\mathrm{~kg} \cdot \mathrm{ha}^{-1}$ & 0.8922 \\
2.5900 & $\mathrm{mile}$ & $\mathrm{km} \mathrm{e}^{2}$ & 0.3861 \\
305.1517 & $\mathrm{oz} / \mathrm{ft}^{2}$ & $\mathrm{~g} \cdot \mathrm{m}^{-2}$ & 0.0033 \\
1 & $\mathrm{ppm}$ & $\mathrm{mg} \cdot \mathrm{kg}^{-1}$ & 1
\end{tabular}


the volume used by residents with moveable sprinklers $(420,000$ versus 230,000 L per month) (Osmond and Hardy, 2004). The 1995 survey of Florida residents indicated that $41 \%$ of respondents had fixed irrigation systems installed in their landscapes (Knox et al., 1995). The number of landscapes irrigated with fixed irrigation systems has likely increased since 1995 because the majority of new homes are built with in-ground irrigation systems (Tampa Bay Water, 2005; Whitcomb, 2005). As a result, it is probable that overwatering has also increased since that time and that overwatering is presumably common throughout Florida. Additionally, the survey of Florida residents conducted by Knox et al. (1995) indicated that only $15 \%$ of respondents used lowvolume irrigation, but $80 \%$ were watering landscapes during the recommended early morning or evening hours.

Results of homeowner surveys in Florida and Georgia suggested that $\approx 25 \%$ of homeowners employ a maintenance professional to manage the ornamental plants and turf in their home landscapes (Israel and Knox, 2001; Varlamoff et al., 2001). However, it is likely that homeowners retain control over the application of irrigation to landscapes.

Commercial LANDSCAPE professionals. Commercial landscape professionals are responsible for the installation and maintenance of landscapes and/or irrigation systems at residential, public, and commercial properties. A survey of Florida commercial landscape professionals indicated that $46 \%$ of respondents applied fertilizer to ornamental landscape plants three or more times per year. Most of the professionals surveyed also indicated that they were fertilizing mature trees and shrubs (Israel et al., 1995). A more recent survey of landscape maintenance and lawn care professionals in the Atlanta area indicated that $68 \%$ of respondents fertilized ornamental beds. Landscape professionals indicated that complete fertilizers [those containing sources of nitrogen $(\mathrm{N})$, phosphorus $(\mathrm{P})$, and potassium $(\mathrm{K})$ ] were most commonly used on ornamentals. Visual appearance and soil testing were reported as methods used to determine fertilizer application; however, these results were misleading because $88 \%$ of respondents indicated that they applied fertilizer according to a predetermined schedule. Spring application of $\mathrm{N}$ fertilizer was the most common practice reported, possibly as a result of the planting of new ornamental beds during this period (Beverly et al., 1997). When surveyed about irrigation, Florida professionals indicated that they dealt primarily with fixed irrigation systems ( $88 \%$ of respondents) and that watering was scheduled for early morning or evening hours (Israel et al., 1995).

\section{Educational opportunities for homeowners and commercial landscape professionals}

Homeowners. Over the years, a variety of educational programs related to proper landscape management has been offered to homeowners, gardeners, and landscape professionals through the Florida Cooperative Extension Service. Surveys indicate that these educational programs have led to the adoption of University of FloridaInstitute of Food and Agricultural Sciences (UF-IFAS) -recommended fertilizer and irrigation practices among program participants (Israel et al., 1995, 1999; Knox et al., 1995). Adoption of recommended fertilizer and irrigation practices has been best when the behavior change had low costs or required limited additional effort. For homeowners, the Florida Cooperative Extension Service currently provides education and outreach programming on landscape management practices designed to reduce the risk for pollution and conserve water through the Florida Yards and Neighborhoods (FYN) and Master Gardener programs. To date, information to determine the adoption rate of FYN practices among Florida homeowners or the effect of these practices on water use in and nutrient losses from residential landscapes is limited.

COMMERCIAL LANDSCAPE PROFESSIONALS. Certification programs for commercial landscape professionals are becoming more common throughout Florida. The Florida Green Industries BMPs program offered by UF-IFAS provides training for landscape professionals related to irrigation system design and fertilizer use (turf and ornamentals). Certification programs are also offered to landscape professionals through the Florida Nursery Growers and Landscape Association and the International Society of Arboriculture. The Landscape Maintenance Association is currently developing a certification program. Regardless of the availability of these programs, the reality is that most landscape professionals have not received formal training on fertilizer use or irrigation management.

\section{Available information related to fertilizers for ornamental landscape plants}

Fertilizer products. There is very little information about the use of specific fertilizer sources for ornamentals by homeowners and landscape professionals. Also, the availability of specific fertilizer sources varies with location throughout the state. Browsing through the inventory of ornamental fertilizers at a national "big-box" store chain in the Tampa Bay region, we found that granular, liquid, polymer-coated, and fertilizer spike products are widely available to area consumers. Most of the fertilizers available to homeowners for use on ornamentals in the landscape are complete fertilizer blends (containing $\mathrm{N}, \mathrm{P}$, and $\mathrm{K}$ ) that are formulated primarily using inorganic materials in both soluble and slow- or controlled-release formulations; some also contain micronutrients. Consumers also have access to specialty fertilizers for palms (Arecaceae) ( $8 \mathrm{~N}-$ $0.9 \mathrm{P}-10 \mathrm{~K}-4 \mathrm{Mg}$ ) that have been formulated based on UF-IFAS research (Broschat, 2001). A wide variety of fertilizer products are available to commercial landscape professionals because they have access to singlenutrient fertilizers and can blend them accordingly.

Fertilization rates. Few studies have investigated optimum fertilization of ornamental plants growing in the landscape; most have focused on the nutrient requirements of selected woody shrubs and tree species. Information about the fertilizer requirements of annuals and perennials in the landscape is lacking. In addition, research on fertilizer needs of ornamentals tends to focus heavily on $\mathrm{N}$ needs of the plants because most of the available research showed no growth or color response to applications of $\mathrm{P}$ or K. For example, Gilman and Yeager 
(1990) reported no response to applications of $\mathrm{P}$ and $\mathrm{K}$ to established live oak trees (Quercus virginiana). Gilman et al. (2000) also reported no growth response to $\mathrm{P}$ and $\mathrm{K}$ applications during establishment or maintenance of live oak or southern magnolia (Magnolia grandiflora). Establishment is a broad term that is frequently used by many authors in various ways. It is used most frequently to refer to the general stage of plant growth that occurs between transplanting and the resumption of "normal growth" after the root system has redeveloped. That is the general definition used for the term in regard to this review. It has also been suggested that research has been focused on $\mathrm{N}$ because excessive applications may result in water quality degradation or plant problems (e.g., pests, diseases, winter injury, and so on) (Perry and Hickman, 1998).

Researchers have evaluated the response of several woody species to $\mathrm{N}$ fertilizers. For example, growth and color response of hibiscus (Hibiscus rosa-sinensis) to surface applications of liquid urea or slow-release $\mathrm{N}$ (applied to a $64-\mathrm{ft}^{2}$ area around the plant) were evaluated in sandy, alkaline soils (E.F. Gilman and P. Giaque, unpublished data). Researchers found that $\mathrm{N}$ applied at $5 \mathrm{lb} / 1000 \mathrm{ft}^{2}$ per year (in five equal applications) produced acceptable leaf color for a period of 3 to 4 weeks and plants receiving $\mathrm{N}$ at a rate of $15 \mathrm{lb} / 1000$ $\mathrm{ft}^{2}$ per year (in five equal applications) maintained leaf color until just before the next fertilizer application $(\approx 7$ to 8 weeks). Leaf color, twig length, and flowers per plant all increased with increasing $\mathrm{N}$ rate from 0.5 to $3.0 \mathrm{lb} /$ $1000 \mathrm{ft}^{2}$ per application (E. F. Gilman and $\mathrm{P}$. Giaque, unpublished data). Nitrogen fertilizer rates of 0.5 to 3 $\mathrm{lb} / 1000 \mathrm{ft}^{2}$ per year were reported as suitable for japanese holly (Ilex crenata), forsythia (Forsythia spp.), and crape myrtle (Lagerstroemia spp.) when applied using liquid soil injection or liquid surface drench (Rose and Joyner, 2003).

Research also indicates that response of trees and shrubs to fertilization is influenced by environmental factors. For example, fertilizer studies conducted by a professional landscape company (TruGreen, Memphis, TN) on trees and shrubs ranging from 1 to 10 years of age growing in the landscape showed little to no fertilizer response to $\mathrm{N}$ application when plants were grown in fertile field soils (Rose and Joyner, 2003). Similar findings are reported by Broschat et al. (2008) for pentas (Pentas lanceolata), dwarf allamanda (Allamanda cathartica), and nandina (Nandina domestica). Gilman and Yeager (1990) and Gilman et al. (2000) also reported similar growth of laurel oak (Quercus laurifolia), japanese ligustrum (Ligustrum japonicum), southern magnolia, and live oak in fertile soils both with and without fertilization. In contrast, trees and shrubs showed a significant response to $\mathrm{N}$ fertilizers when plants were grown in recreated soils (using subsoil material of low fertility) that would be typical of those encountered in urban landscapes by inverting the soil profile (Rose and Joyner, 2003).

Nitrogen fertilization standards for woody ornamental plant maintenance have been developed by the National Arborist Association (American National Standards Institute, 2004). The recommended $\mathrm{N}$ rates are from 1 to $6 \mathrm{lb} / 1000 \mathrm{ft}^{2}$ per year (American National Standards Institute, 2004). According to Rose (1999), these recommendations were based on research to determine the maximum fertilizer response that was conducted from the 1950 s to the 1970s. Rose (1999) also reports that these recommendations are higher than those for agronomic crops and provide less guidance for selecting a rate within the range. TruGreen reports $\mathrm{N}$ application rates of 1.5 $\mathrm{lb} / 1000 \mathrm{ft}^{2}$ per application (two applications per year) for ornamental plants (Rose and Joyner, 2003).

Both the Florida Green Industries BMPs manual (Florida Department of Environmental Protection, 2002) and the current FYN handbook (FYN, 2006) provide $\mathrm{N}$ fertilizer rate recommendations for established ornamental plants (excluding palms) in the landscape (Table l) that generally agree with the American National Standards Institute recommendations; however, neither publication references applications of $\mathrm{P}$ or $\mathrm{K}$ for ornamental landscape plants. The recommended $\mathrm{N}$ rates have been categorized based on a level of desired maintenance; however, definitions for basic, moderate, and high maintenance are not provided in either document (Florida Department of Environmental Protection, 2002; FYN, 2006). In contrast, the
Table 1. Recommended annual nitrogen $(\mathrm{N})$ fertilizer rates for established landscape plants in Florida (Florida Department of Environmental Protection, 2002; Florida Yards and Neighborhoods, 2006).

\begin{tabular}{lc}
\hline $\begin{array}{l}\text { Level of } \\
\text { maintenance }\end{array}$ & $\begin{array}{c}\text { Recommended } \\
\mathbf{N} \text { rates } \\
\left(\mathbf{l b} / \mathbf{1 0 0 0} \mathrm{ft}^{2}\right)^{\mathbf{y}}\end{array}$ \\
\hline Basic & $0-2$ \\
Moderate & $2-4$ \\
High & $4-8$ \\
\hline
\end{tabular}

${ }^{\mathrm{z}}$ Definitions for basic, moderate, and high level of maintenance are not provided in the referenced documents.

${ }^{\mathrm{y}} \mathrm{llb} / 1000 \mathrm{ft}^{2}=48.8243 \mathrm{~kg} \cdot \mathrm{ha}^{-1}$

UF-IFAS Extension Soil Testing Laboratory recommends $\mathrm{N}$ application rates of $2.3 \mathrm{lb} / 1000 \mathrm{ft}^{2}$ per year (Kidder et al., 1998) for most woody ornamentals in the landscape. The only exceptions are azalea (Rhododendron spp.), camellia (Camellia spp.), gardenia (Gardenia spp.), hibiscus, and ixora (Ixora coccinea), which have an $\mathrm{N}$ recommendation of $1.1 \mathrm{lb} / 1000 \mathrm{ft}^{2}$ per year. This information is provided as part of the landscape and vegetable garden soil test report. In addition, fertilizer $\mathrm{P}$ and $\mathrm{K}$ rate recommendations are based on Mehlich 1 soil test results (Mylavarapu and Kennelley, 2002) (Tables 2 and 3). The basis for these low $\mathrm{P}$ and $\mathrm{K}$ fertilizer recommendations for ixora is not known. Broschat (2000) determined that $\mathrm{P}$ and $\mathrm{K}$ deficiencies are a widespread and serious problem for ixora grown in Florida landscapes.

Fertilization timing. As is the case with fertilizer rates, information on the timing of fertilizer application for nonwoody components of the landscape is notably missing. For woody ornamental plants during maintenance, the American National Standards Institute fertilization standards state that "fertilizer should be applied so that nutrients are available when roots are actively growing" (American National Standards Institute, 2004). This provides little guidance about actual timing of fertilizer applications, because it is difficult to determine when root growth is occurring. The majority of U.S. states recommend that fertilizers be applied in early spring (before budbreak) or late fall (after leaf drop) or that the fertilizer applications be split between the two seasons (Rose, 1999). This 
recommendation is similar to the calendar-based applications made by TruGreen (Rose and Joyner, 2003). According to Rose and Joyner (2003), these recommended seasonal fertilizer applications contradict fruit crop research, which has indicated that little nutrient uptake occurs before bud break or after leaf drop. Similarly, the $\mathrm{N}$ use efficiency of shade trees (grown in temperate regions) is low in early spring and high in the summer with plant $\mathrm{N}$ uptake increasing between periods of shoot growth. During this time, leaves become a carbohydrate source, rather than a carbohydrate sink, which stimulates root growth and N uptake (Struve, 2002). Struve (2002) also reports that spring-applied $\mathrm{N}$ is used by the plant during that season but that it only contributes $25 \%$ of the total $\mathrm{N}$ in the foliage. The other $75 \%$ was $\mathrm{N}$ absorbed in the previous season. There has been limited research on timing of fertilizer applications for woody plants in tropical or subtropical climates where growth can be year-round or linked to wet-dry seasonal cycles.

The Florida Green Industries BMPs manual and the current FYN handbook do not provide information about the timing of fertilizer applications (Florida Department of Environmental Protection, 2002; FYN, 2006). However, the UF-IFAS Extension Soil Testing Laboratory recommends that
$\mathrm{P}$ fertilizer be broadcast in one or two yearly applications, whereas $\mathrm{N}$ and $\mathrm{K}$ should be applied every 12 weeks (three times per growing season), adding $33 \%$ of the recommended amount at each application (Kidder et al., 1998). In contrast, TruGreen makes two applications per year (spring and fall) to ornamental plants (Rose and Joyner, 2003). There is little or no information about fertilizer rates, application methods, or timing used by other landscape companies. It can only be assumed that it varies widely and that applications tend to be based on a timed schedule (Beverly et al., 1997).

Fertilization with $\mathrm{N}$ at the time of planting or during the establishment period has been reported to have little or no benefit for trees. A study of fertilization of southern magnolia and live oak by Gilman et al. (2000) reported that "addition of fertilizer was not necessary for survival or growth...in the first 3 to 4 years after transplanting." Ferrini and Baietto (2006) also report that tree $\mathrm{N}$ fertilization was most effective in the third year after planting. However, the effect of $\mathrm{N}$ fertilization soon after planting may be species-dependent. For example, research showed no response of live oak (Gilman et al., 2000) and sugar maple (Acer saccharum) (van de Werken, 1981) to $\mathrm{N}$ application during establishment, whereas southern magnolia showed faster growth after

Table 2. Mehlich-1 soil test interpretations used for environmental horticulture crops in Florida (Kidder et al., 1998).

\begin{tabular}{lccccc}
\hline & \multicolumn{5}{c}{ Soil test level } \\
\cline { 2 - 6 } Element & $\begin{array}{c}\text { Very low } \\
\left(\mathbf{m g} \cdot \mathbf{k g}^{-1}\right)^{\mathbf{z}}\end{array}$ & $\begin{array}{c}\text { Low } \\
\left(\mathbf{m g} \cdot \mathbf{~ k g}^{-1}\right)\end{array}$ & $\begin{array}{c}\text { Medium } \\
\left(\mathbf{m g} \cdot \mathbf{k g} \mathbf{- 1}^{-1}\right)\end{array}$ & $\begin{array}{c}\text { High } \\
\left(\mathbf{m g} \cdot \mathbf{k g}^{-1}\right)\end{array}$ & $\begin{array}{c}\text { Very high } \\
\left(\mathbf{m g} \cdot \mathbf{~ k g}^{-1}\right)\end{array}$ \\
\hline Phosphorus & $<10$ & $10-15$ & $16-30$ & $31-60$ & $>60$ \\
Potassium & $<20$ & $20-35$ & $36-60$ & $61-125$ & $>125$ \\
Magnesium & & $<15$ & $15-30$ & $>30$ & \\
\hline
\end{tabular}

${ }^{\mathrm{z}} \mathrm{l} \mathrm{mg} \cdot \mathrm{kg}^{-1}=1 \mathrm{ppm}$
$\mathrm{N}$ applications during the first year after transplant (Gilman et al., 2000).

Fertilization practices in nursery production appear to have an effect on the rate of establishment and growth of woody ornamentals after planting in the landscape. Cabrera and Devereaux (1999) found that increased $\mathrm{N}$ fertilization during nursery production had a positive effect on posttransplant growth of crape myrtle. However, flowering was delayed in those plants grown under higher $\mathrm{N}$ conditions. Gilman et al. (1996) also report greater posttransplant shoot growth in burford holly (Ilex cornuta 'Burfordii nana') that received more $\mathrm{N}$ fertilizer during production. However, they also report slower posttransplant root growth for plants produced under higher $\mathrm{N}$ conditions. Lloyd et al. (2006) also investigated the effects of "nutrient loading" in the nursery on posttransplant performance. They found that growth of crabapple (Malus spp.) was enhanced when the plants were produced under high $\mathrm{N}$ conditions. However, their findings suggest that "nutrient loading" reduced posttransplant plant resistance to certain insects and decreased drought tolerance. The effect of $\mathrm{N}$ fertilization in nursery production did not manifest itself beyond the year of transplant. Broschat et al. (2008) concluded that container-grown plants established slowly in the landscape as a result of $\mathrm{N}$ deficiency in the pine bark-based container substrate within the root ball.

Fertilizer application METHoDs. Fertilizer application method may also influence plant response. Research conducted by TruGreen suggested that injection and drench applications of urea provided better plant response than dry surface applications (Rose and Joyner, 2003). However, in

Table 3. Target $\mathrm{pH}$ and recommended annual fertilizer rates for ornamentals in Florida landscapes. ${ }^{\mathrm{z}}$

\begin{tabular}{|c|c|c|c|c|c|c|c|c|c|c|c|c|}
\hline \multirow[b]{2}{*}{ Crop description } & \multirow[b]{2}{*}{$\begin{array}{c}\text { Target } \\
\mathrm{pH}\end{array}$} & \multirow[b]{2}{*}{$\begin{array}{c}\text { Nitrogen } \\
\left(1 \mathrm{~b} / 1000 \mathrm{ft}^{2}\right)^{\mathrm{y}}\end{array}$} & \multicolumn{5}{|c|}{$\mathrm{P}_{2} \mathrm{O}_{5}\left(\mathrm{lb} / 1000 \mathrm{ft}^{2}\right)$} & \multicolumn{5}{|c|}{$\mathrm{K}_{2} \mathrm{O}\left(\mathrm{lb} / 1000 \mathrm{ft}^{2}\right)$} \\
\hline & & & $\begin{array}{l}\text { Very } \\
\text { low }\end{array}$ & Low & Medium & High & $\begin{array}{l}\text { Very } \\
\text { high }\end{array}$ & $\begin{array}{l}\text { Very } \\
\text { low }\end{array}$ & Low & Medium & High & $\begin{array}{l}\text { Very } \\
\text { high }\end{array}$ \\
\hline $\begin{array}{l}\text { Azalea, camellia, } \\
\text { gardenia, hibiscus, } \\
\text { or ixora in } \\
\text { the landscape }\end{array}$ & 5.5 & 1.1 & 0.3 & 0.3 & 0.2 & 0 & 0 & 0.7 & 0.7 & 0.3 & 0 & 0 \\
\hline
\end{tabular}

${ }^{2}$ Phosphorus and potassium rates (expressed in the oxide forms $\mathrm{P}_{2} \mathrm{O}_{5}$ and $\mathrm{K}_{2} \mathrm{O}$, respectively) are based on interpretation of a Mehlich-1 soil test (Kidder et al., 1998 ).

${ }^{\mathrm{y}} \mathrm{llb} / 1000 \mathrm{ft}^{2}=48.8243 \mathrm{~kg} \cdot \mathrm{ha}^{-1}$. 
a review of shade tree $\mathrm{N}$ fertilization research, Struve (2002) states that surface application of $\mathrm{N}$ fertilizer is as effective as soil injection or soildrilling techniques. The Florida Green Industries BMPs manual and the current FYN handbook suggest that fertilizers for ornamentals be broadcast uniformly over the desired landscape area (Florida Department of Environmental Protection, 2002; FYN, 2006).

FERTILIZER TYPE. Researchers evaluated the response of hibiscus to applications of urea or slow-release $\mathrm{N}$ at 0,1 , or $2 \mathrm{lb} / 1000 \mathrm{ft}^{2}$ per application (four applications per year) and found that slow-release fertilizers produced more growth than soluble fertilizer applications (E.F. Gilman and P. Giaque, unpublished data). In contrast, another study showed no significant difference in growth of japanese holly receiving $50 \%$ slow-release or soluble urea during the first 2 years after planting (Rose and Joyner, 2003). Broschat et al. (2008) found that cannas (Canna $\times$ generalis) and areca palms (Dypsislutescens) had higher quality (less severe nutrient deficiency symptoms) when fertilized with an $8 \mathrm{~N}-0.9 \mathrm{P}-10 \mathrm{~K}-4 \mathrm{Mg}$ slow-release fertilizer than with a mostly water soluble $24 \mathrm{~N}-0.9 \mathrm{P}-9.1 \mathrm{~K}$ product. However, there were no differences in size or quality among dwarf allamandas or pentas that were similarly fertilized.

Palms in the landscape present special problems because they are subject to a number of debilitating and even fatal nutrient deficiencies (Broschat, 2005). Broschat (2001) developed a fertilizer with an analysis of $8 \mathrm{~N}-0.9 \mathrm{P}-10 \mathrm{~K}-4 \mathrm{Mg}$ for palms growing in Florida landscapes. Palms have extensive root systems and will absorb nutrients from fertilizers applied to turfgrasses some distance away, often with detrimental results. Thus, Knox et al. (2002) and Trenholm et al. (2002) each indicate that landscape areas that are to be fertilized within $30 \mathrm{ft}$ of a palm should be fertilized with the $8 \mathrm{~N}-0.9 \mathrm{P}-10 \mathrm{~K}-4 \mathrm{Mg}$ formulation.

\section{Available information related to water use and requirements of ornamental landscape plants}

IrRigATION SOURCES. In Florida, the main water source for irrigation of ornamental landscape plants is potable water from the public supply or from a private well. On the central Florida Ridge, potable water used for landscape irrigation has been found to be as high as $74 \%$ of total household consumption with an average of 64\% (Haley et al., 2007), even when irrigation was restricted to $2 \mathrm{~d}$ per week (St. Johns River Water Management District, 2006). During the last several years, there has been an expansion of infrastructure to allow for the use of reclaimed water (treated domestic wastewater) for irrigation of urban landscapes. As of 2006, there were 216,248 home landscapes in Florida that could be irrigated using reclaimed water (Florida Department of Environmental Protection, 2007). There are some concerns related to the use of reclaimed water for irrigation of landscape ornamentals. In particular, reclaimed water may contain higher levels of salt than potable water, which may impact the health of some ornamentals. Also, reclaimed water may contain plant-available nutrients such as nitrate and phosphate. When irrigating with reclaimed water, these soluble nutrients should be considered before applying additional fertilizers (Dukes et al., 2008).

IRrigation TIMING. Depending on location in Florida, the irrigation of commercial and residential landscapes with potable water may be restricted as a result of widespread drought conditions. Currently, the Northwest Florida Water Management District does not impose watering restrictions for lawn and landscape irrigation. However, the district has issued water shortage notification and has asked for voluntary use reductions. The South Florida Water Management District and St. Johns River Water Management District allow irrigation $2 \mathrm{~d}$ per week between 1600 and 1000 HR (South Florida Water Management District, 2008; St. Johns River Water Management District, 2008). The Southwest Florida Water Management District has the most stringent watering restrictions, allowing irrigation $\mathrm{l} \mathrm{d}$ per week (based on address) between 1800 and $0800 \mathrm{HR}$ (Southwest Florida Water Management District, 2008). All restrictions allow hand watering, microirrigation of nonturf areas, and provide exceptions for newly installed landscape plant material. Fewer restrictions exist on the use of reclaimed water for landscape irrigation. In fact, only the
South Florida Water Management District restricts the use of reclaimed water; allowing irrigation between 1600 and 1000 HR daily, with the exception of Fridays when no watering is allowed (South Florida Water Management District, 2008).

IRRIGATION SCHEDULING. Many Florida homeowners are subject to watering restrictions, which limit the frequency and time of day that irrigation can be scheduled. Most of the ornamental plants that receive irrigation are on a timed schedule and it is likely that the majority of Florida homeowners with in-ground irrigation systems use the "set it and forget it" approach to irrigation scheduling. Research has shown that setting irrigation time clocks monthly based on UF-IFAS recommendations (Dukes and Haman, 2002) can reduce irrigation water applied to residential landscapes by up to $30 \%$ (Haley et al., 2007). In general, research in Florida has indicated that irrigation is often applied in excess of plant water needs. Thus, achieving control of irrigation application will likely lead to more immediate water conservation benefits.

Irrigation scheduling based on soil moisture status or evapotranspiration (ET) also has the potential to reduce water use in residential landscapes. A central Florida study demonstrated that irrigation controlled by soil moisture sensors had the potential to save up to $90 \%$ of the irrigation water that would be used if irrigation was applied on a time-based schedule (Cardenas-Laihacar et al., 2008). When soil moisture sensor technology was implemented on established home landscapes, irrigation water use was reduced by as much as a $51 \%$ (Haley and Dukes, 2007). Another study demonstrated that irrigation scheduling using ET controllers was able to reduce the volume of water used on mixed landscapes compared with time-based irrigation methods without negative impacts on ornamental plant growth or quality (A.L. Shober, unpublished data; M.D. Dukes, unpublished data). Rain sensor shutoff devices are another irrigation technology designed to reduce outdoor water use and are mandated on all new irrigation systems in Florida. They have not been extensively studied for their water conservation potential, but Cardenas-Laihacar et al. 
(2008) demonstrated that rain sensors could reduce irrigation by $17 \%$ to $44 \%$.

Irrigation Strategies. More efficient use of in-ground irrigation systems could also reduce outdoor water use by homeowners. Irrigation strategies that improve the efficiency of fixed irrigation systems include: 1 ) conducting periodic checks of the irrigation system to ensure proper coverage and system function; 2) watering in the early morning $(0400$ to $0700 \mathrm{HR}$ ); 3 ) using microirrigation systems for ornamental plant beds; 4) watering less in cooler months or when there is adequate rainfall; and 5 ) selection and proper hydrozoning of plants. Research indicates that replacing sprinkler-irrigated areas with microirrigated ornamental areas (from $100 \%$ to $35 \%$ sprinkler-irrigated area) further increased irrigation savings to $50 \%$ (Haley et al., 2007). Selection of drought-tolerant plants may reduce water use in the long term; however, landscapes consisting of entirely mixed ornamentals (no turf) have been shown to have higher water requirements during establishment relative to properly maintained turfgrass (Park et al., 2005).

WATER REQUIREMENTS OF ORNAMENTAL PLANTS IN THE LANDSCAPE. There is a wide body of research related to the water needs of ornamental landscape plants during production. In contrast, information about the water requirements/use for establishment and maintenance of ornamental plants grown in the landscape is limited. Often landscape plants are assigned to water use categories based on anecdotal evidence of plant performance under various water stress conditions. For example, California uses the landscape coefficient method to estimate irrigation needs of landscape plants. As part of this method, landscape plants were placed into categories of water needs based on the scientific judgment of selected committee members rather than actual measurements of water use/requirements in the field (Costello and Jones, 1998).

Most of the research evaluating the water use or drought tolerance of ornamental plants has involved plants growing in pots and/or growing in the arid western U.S. states (GarciaNavarro et al., 2004; Levitt et al., 1995; Zollinger et al., 2006). Levitt et al. (1995) evaluated the water use of live oak and mesquite (Prosopis alba 'Colorado') in containers and found that under nonstress conditions, mesquite (xeric tree) required more water than the live oak (mesic tree). In a study conducted in Utah, Zollinger et al. (2006) evaluated the drought tolerance of six herbaceous perennials during establishment and maintenance phases in a 3.8-L pot-in-pot system. Response to water stress conditions varied with some species exhibiting dieback when water was insufficient. The researchers were able to rank the six species based on tolerance to mild, moderate, or severe drought conditions; however, the impact of drought conditions on plants grown in pots may differ significantly from conditions when plants are grown in the landscape. Garcia-Navarro et al. (2004) showed that the relative water use by four woody landscape species in 3.8 - $\mathrm{L}$ containers was significantly correlated to water use by the same species grown in the landscape, suggesting that water use at the end of production could be useful to predict water needs during landscape establishment.

A recent study by Scheiber et al. (2007) evaluated the effect of 2-, 4-, or 7-d irrigation frequencies on growth, aesthetic quality, and establishment of three shrub species, burford holly (Ilex cornuta), japanese pittosporum (Pittosporum tobira), and sweet viburnum (Viburnum odorotissimum), in central Florida. Plants received $3 \mathrm{~L}$ of water per irrigation event, which was delivered through a microirrigation system. Results of this study suggested that plant growth and quality were similar for all irrigation treatments; however, plants watered every 2 or $4 \mathrm{~d}$ established $\approx 1$ to 2 months earlier than shrubs watered once per week. Results of this study also suggest that the $60 \mathrm{~d}$ or less of daily irrigation allowed for establishment of new plantings during periods of water restriction is not sufficient to ensure establishment of woody ornamentals. This conclusion is supported by study results for live oak (Gilman, 2001). The shrub establishment research has been repeated at three locations throughout Florida (northern, central, and southern). Results suggest that watering every $8 \mathrm{~d}$ was sufficient for establishment of the shrubs in northern and central Florida. However, results from southern Florida suggest that plants will establish within 20 to 28 weeks after transplant when watered every 4 d (Moore et al., 2009; Shober et al., 2009; Wiese et al., 2009).

Irrigation frequency seems to affect tree root growth. Frequent irrigation for 24 weeks resulted in increased root number, root cross-sectional area, and uniformity of root distribution for red maple (Acer rubrum) (Gilman et al., 2003). "Frequent" irrigation was defined as $38 \mathrm{~L}$ of water daily during Weeks 2 through 9 and then every other day during Weeks 9 through 24 in this study. Vertical distribution of roots of red maple and burford holly were affected by irrigation frequency. In both cases, root systems were shallower in plants receiving more frequent irrigation (Gilman et al., 1996, 2003). Survival of live oak also increased with irrigation frequency and duration (Gilman, 2001; Gilman et al., 1998). Irrigation for only 6 weeks after transplanting resulted in $58 \%$ survival compared with $100 \%$ survival for trees that received irrigation two times per week for several months after planting (Gilman, 2001). Irrigation frequency seems to be more critical for the survival of container-grown trees when compared with field-grown plants (Gilman, 2001; Marshall and Gilman, 1997).

\section{Factors that affect water and nutrient use efficiency in the landscape}

Site DESIGN AND PREPARATION. When designing and preparing for new landscapes, most resources are allocated to the planting materials and above-ground installations with little attention placed on the soil quality (Jim, 1998). Soil compaction is required for site stabilization of the home site during construction. The small lot sizes for new Florida homes often means that the entire lot, not just the home site, is compacted by heavy equipment and constant traffic during construction (Gregory et al., 2006). Soil compaction in the landscaped areas can result in: 1) limited root development, which is needed for healthy plant establishment; and 2 ) a reduction in infiltration rates, which leads to runoff and nutrient loss (Jim, 1998; Rivenshield and Bassuk, 2007; Whalley et al., 1995). In addition, soil compaction, which is 
quantified by high bulk density, affects the transport, adsorption, and transformation of nutrients. Compaction can impact the plant availability of nutrients and water (Lipiec and Stepniewski, 1995). Homeowners and landscape professionals may mistakenly apply additional water and fertilizers to landscape plants that exhibit nutrient and water stresses in compacted landscapes.

Construction activities that occur as a result of urbanization have also been shown to impact water quality. Gregory et al. (2006) showed that compaction of the soil during construction had the ability to significantly decrease infiltration and increase the amount of runoff from developed areas in north-central Florida. Similarly, Law et al. (2004) suggested that soil compaction may reduce $\mathrm{N}$ leachate potential to the surficial aquifer but increase runoff potential. In the United Kingdom, soils in areas of home construction were found to have high (vertical and horizontal) spatial soil nitrate variability as a result of topsoil stripping and soil compaction during construction (Wakida and Lerner, 2006). Concentrations of nitrate- $\mathrm{N}$ in these U.K. soil profiles ranged from an average $6 \mathrm{~kg} \cdot \mathrm{ha}^{-1}$ in the vegetated control sites to 28 to $138 \mathrm{~kg} \cdot \mathrm{ha}^{-1}$ in the construction sites, suggesting that construction practices can increase the risk for $\mathrm{N}$ leaching (Wakida and Lerner, 2006).
Runoff monitoring from small (less than 7 ha) drainage areas of relatively homogeneous land uses (residential, golf course, industrial, pasture, construction site) in the Neuse River Basin (North Carolina) indicated that total $\mathrm{N}$ export was greatest for the construction site during the housebuilding phase ( $\mathrm{N}$ at $36.3 \mathrm{~kg} \cdot \mathrm{ha}^{-1}$ ) followed closely by the residential and golf course land uses. Total P export was greatest for the golf course site $(\mathrm{P}$ at $5.3 \mathrm{~kg} \cdot \mathrm{ha}^{-1}$ ) followed by the pasture and residential land uses (Line et al., 2002). These studies suggest that nutrient loss in runoff and/or leachate from urban landscapes is a legitimate concern.

Plant selection and zoning. Selection of resource-efficient landscape plant materials has the potential to reduce fertilizer and irrigation use in the landscape. Information about plant water requirements and "droughttolerant" plants is available in numerous sources like the Florida-Friendly Plant List (Wichman et al., 2006) and the WaterWise plant list (South Florida Water Management District, 2003). However, the information in these sources is anecdotal and does not provide actual water requirements. Instead, they place species into broad categories (i.e., low, medium, and high), similar to the California model described previously. This information can be used to attempt to group plants according to irrigation requirements, but it does not offer insight into the actual amount of water plants in the "medium" category require. Thus, the translation of plant water use category into an actual irrigation system run time and frequency is extremely difficult. Zoning plants according to their irrigation requirement is widely recommended and is one of the principles in Waterwise Landscaping (South Florida Water Management District, 2003), Xeriscaping ${ }^{\mathrm{TM}}$ (Colorado Water Wise Council, 2008), and FloridaFriendly Landscaping (FYN, 2006). There is little information about how effective this strategy is at saving water or how frequently this principle is implemented.

A study investigating the postestablishment landscape performance of Florida native and exotic shrubs under both irrigated and nonirrigated conditions found that the plant's indigenous status did not affect any of the parameters measured (e.g., growth, aesthetic quality) (Scheiber et al., 2008). There are numerous reports of significant variation within taxa for water requirement [e.g., maple (Acer spp.) (St. Hilaire and Graves, 2001; Zwack et al., 1999; Zwack and Graves, 1998), eucalyptus (Eucalyptus spp.) (Li, 1998; Li et al., 2000; Tuomela, 1997), pine (Pinus spp.) (Cregg, 1994), ash (Fraxinus spp.) (Abrams et al., 1990), redbud (Cercis canadensis) (Griffin et al., 2004), and baldcypress (Taxodium

Table 4. Summary of current best management practice (BMP) research areas for landscape plants, level of knowledge, and knowledge gaps in Florida.

\begin{tabular}{|c|c|c|}
\hline $\mathrm{BMP}$ research area & Level of knowledge & Knowledge gaps \\
\hline $\begin{array}{l}\text { Fertilizer requirements of ornamental } \\
\text { landscape plants in the landscape }\end{array}$ & Incomplete & $\begin{array}{l}\text { No information on nonwoody species (except palms); } \\
\text { need research during establishment and } \\
\text { maintenance phases }\end{array}$ \\
\hline $\begin{array}{l}\text { Water needs of ornamental landscape } \\
\text { plants in the landscape }\end{array}$ & Incomplete & $\begin{array}{l}\text { Need statewide information for other species; } \\
\text { need to look at additional factors (planting season, } \\
\text { plant size, soil type/nutritional status) }\end{array}$ \\
\hline Management of soil in urban landscapes & Incomplete & $\begin{array}{l}\text { Information available for soil compaction effects on } \\
\text { tree and woody species only; need more } \\
\text { information about impacts of soil compaction } \\
\text { on nutrient losses from landscapes }\end{array}$ \\
\hline
\end{tabular}


Table 5. Questions to and summary of vision statements by University of Florida-Institute of Food and Agricultural Sciences (UF-IFAS) state and county faculty with active programs in best management practices (BMPs) for landscape ornamentals (nonturf).

\begin{tabular}{|c|c|c|}
\hline Question & Need or issue & Comments \\
\hline $\begin{array}{l}\text { What is your opinion/vision for the } \\
\text { next } 5 \text { years on what homeowners or } \\
\text { commercial landscape professionals } \\
\text { need to do to improve irrigation } \\
\text { management for ornamental plants? }\end{array}$ & $\begin{array}{l}\text { Install drip irrigation for trees and shrubs } \\
\text { Conduct periodic checks of irrigation } \\
\text { systems for leaks or broken/misaligned } \\
\text { heads } \\
\text { Move toward irrigation based on soil } \\
\text { moisture or plant wilt symptoms, } \\
\text { not time-based systems } \\
\text { Manage irrigation system time } \\
\text { clocks properly } \\
\text { Group plants according } \\
\text { to water needs } \\
\text { Understand the effect of irrigation } \\
\text { practices on the watershed and } \\
\text { water supply } \\
\text { Provide more stringent certification } \\
\text { programs for industry } \\
\text { Hire certified professionals (homeowners) } \\
\text { Enforce watering restrictions } \\
\text { more consistently }\end{array}$ & $\begin{array}{l}\text { Most problems with irrigation systems } \\
\text { go unnoticed because watering } \\
\text { restrictions require irrigation during } \\
\text { nondaylight hours } \\
\text { Effective irrigation controllers are needed } \\
\text { to take the responsibility out of the } \\
\text { hands of the homeowner }\end{array}$ \\
\hline $\begin{array}{l}\text { What is your opinion/vision for the next } \\
5 \text { years on what homeowners or } \\
\text { commercial landscape professionals } \\
\text { need to do to improve their fertilizer } \\
\text { management for ornamental plants? }\end{array}$ & $\begin{array}{l}\text { Educate more people about how to } \\
\text { read a fertilizer label correctly } \\
\text { Instill more appreciation of water quality } \\
\text { issues related to fertilizer } \\
\text { Understand that more fertilizer is not } \\
\text { always better (established trees and } \\
\text { shrubs may need no fertilizer) } \\
\text { Shift from water soluble fertilizers to } \\
\text { "slow- or controlled-release" products } \\
\text { Develop products designed for soils } \\
\text { and climatic conditions in Florida, } \\
\text { not the northeastern United States } \\
\text { Install/maintain buffer zones } \\
\text { Shift from timed applications of fertilizers } \\
\text { to fertilization when needed } \\
\text { Choose a fertilizer based on analysis } \\
\text { and cost } \\
\text { Calibrate fertilizer application equipment } \\
\text { Provide more stringent certification } \\
\text { programs for industry } \\
\text { Hire certified professionals (homeowners) }\end{array}$ & \\
\hline $\begin{array}{l}\text { What educational programs are needed? } \\
\text { (need to be separated for agents, } \\
\text { landscape professionals, and } \\
\text { homeowners) }\end{array}$ & $\begin{array}{l}\text { All groups: } \\
\text { There is a lot of information available, } \\
\text { but a better method to disseminate } \\
\text { that information is needed } \\
\text { Develop Spanish materials } \\
\text { Educate clientele about actual plant } \\
\text { phosphorus requirements } \\
\text { Provide information about reclaimed } \\
\text { water, including nutrient levels, } \\
\text { effects on plants, salt content } \\
\text { Develop online materials/tutorials, } \\
\text { and so on } \\
\text { Provide information about fertilizer } \\
\text { sources and properties } \\
\text { Conduct hands-on training for fertilizer } \\
\text { application (including calibration) }\end{array}$ & $\begin{array}{l}\text { Many times BMPs and local government } \\
\text { officials are connected, so it is critical } \\
\text { that UF-IFAS administration, } \\
\text { specialists, and county faculty have } \\
\text { a consistent message; this is especially } \\
\text { important when dealing with issues } \\
\text { that involve emotions such as } \\
\text { water quality }\end{array}$ \\
\hline
\end{tabular}

(Continued on next page) 
Table 5. (Continued) Questions to and summary of vision statements by University of Florida-Institute of Food and Agricultural Sciences (UF-IFAS) state and county faculty with active programs in best management practices (BMPs) for landscape ornamentals (nonturf).

\begin{tabular}{|c|c|c|}
\hline Question & Need or issue & Comments \\
\hline & $\begin{array}{l}\text { Provide irrigation system training } \\
\text { (operation and troubleshooting) } \\
\text { Agents: } \\
\text { Know what the most current research } \\
\text { says and how to use it } \\
\text { Provide public policy/administrative } \\
\text { guidance for county faculty working } \\
\text { with local governments and } \\
\text { state agencies } \\
\text { Provide training on how to conduct } \\
\text { a water audit } \\
\text { Landscape professionals: } \\
\text { Know what the most current research } \\
\text { says and how to use it } \\
\text { Offer training on UF-IFAS } \\
\text { fertilizer recommendations } \\
\text { Homeowners: } \\
\text { Provide information about how, } \\
\text { when, and where to apply fertilizer } \\
\text { Supply information about } \\
\text { fertilizer products } \\
\text { Create more demonstrations for } \\
\text { the Florida Yards and Neighborhoods } \\
\text { (FYN) program in neighborhoods, } \\
\text { parks, and so on } \\
\text { Offer training on conversion from } \\
\text { overhead to microirrigation } \\
\text { Local officials: } \\
\text { Educate officials about what the science } \\
\text { says with a consistent, unbiased message } \\
\text { from UF }\end{array}$ & $\begin{array}{l}\text { When local governments break away from } \\
\text { researched science for guidance } \\
\text { and direction, county faculty are } \\
\text { sometimes forced to teach both "local" } \\
\text { science and "real" science BMPs; } \\
\text { therefore, further discussion is needed } \\
\text { to decide how the University of Florida } \\
\text { should engage public policy as well as } \\
\text { teach alongside "pseudo"-science-based } \\
\text { landscape ordinances; in the end, } \\
\text { it is possible that this guidance will } \\
\text { address water and fertilization policy } \\
\text { issues, thus providing a closer } \\
\text { relationship with local government } \\
\text { based on sound agronomic/ } \\
\text { horticulture principles }\end{array}$ \\
\hline Other & New insect/disease pests & \\
\hline
\end{tabular}

distichum) (Denny et al., 2007)] and nutrient use efficiency [e.g., redbud (Zahreddine et al., 2007), pecan (Carya illinonensis) (Wood et al., 1998), hibiscus (Valdez-Aguilar and Reed, 2006), peach (Prunus persica) (Shi and Byrne, 1995), and baldcypress (Denny et al.,
2006)]. These reports suggest that there is the potential to select or breed ornamental plant material for resource efficiency. One advantage to selecting for resource efficiency within a species that is already used in the landscape is that it may be more readily adopted and used compared with plants that are new or unknown to landscape designers and consumers.

FERTILIZER AND IRRIgATION MANAGEMENT PRACTICES. It has been suggested that the landscape management practices of homeowners and 
Table 6. Strategic areas of future research involving landscape ornamentals (nonturf) for improving the quality of Florida waters, their respective approaches, and estimated chances of success.

\begin{tabular}{|c|c|c|c|}
\hline $\begin{array}{l}\text { Approach used to improve } \\
\text { water quality }\end{array}$ & Possible areas of research & Chance of success & Why? \\
\hline $\begin{array}{l}\text { Reduce nitrogen }(\mathrm{N}) \text { and } \\
\text { phosphorus }(\mathrm{P}) \text { applications } \\
\text { to only situations where } \\
\text { it is required }\end{array}$ & $\begin{array}{l}\text { Determine the } \mathrm{N} \text { and } \mathrm{P} \text { fertilizer } \\
\text { requirements for various } \\
\text { landscape plants and correlate } \\
\text { with soil test levels }\end{array}$ & Good & $\begin{array}{l}\text { High P soils may dominate the } \\
\text { landscape requiring research } \\
\text { in pots or other controlled } \\
\text { situations }\end{array}$ \\
\hline $\begin{array}{l}\text { Use "slow- or controlled-release" } \\
\text { fertilizers }\end{array}$ & $\begin{array}{l}\text { Determine the actual release times } \\
\text { of specific materials }\end{array}$ & Good & $\begin{array}{l}\text { Manufacture release times may } \\
\text { not be accurate for } \\
\text { Florida conditions }\end{array}$ \\
\hline Buffer (no application) zones & $\begin{array}{l}\text { Runoff volume and nutrient } \\
\text { loads reductions with and } \\
\text { without buffer areas }\end{array}$ & Fair & $\begin{array}{l}\text { Need long-term homeowner } \\
\text { buy-in and participation; } \\
\text { need to change homeowner } \\
\text { perception of "waterfront" }\end{array}$ \\
\hline $\begin{array}{l}\text { Optimize fertilizer use efficiency } \\
\text { for ornamentals }\end{array}$ & $\begin{array}{l}\text { Determine the fertilizer response } \\
\text { of ornamentals }\end{array}$ & Excellent & $\begin{array}{l}\text { Research trials are straightforward } \\
\text { with proven methods }\end{array}$ \\
\hline $\begin{array}{l}\text { Fertilize and water ornamentals } \\
\text { appropriately }\end{array}$ & $\begin{array}{l}\text { Determine the effect of many } \\
\text { factors (e.g., planting season, } \\
\text { location in Florida, plant type, } \\
\text { plant size, soil type, and so on) } \\
\text { on the fertilizer and irrigation } \\
\text { needs of ornamentals }\end{array}$ & Good & $\begin{array}{l}\text { Impossible to evaluate every } \\
\text { landscape plant species; } \\
\text { many factors need to be } \\
\text { evaluated individually }\end{array}$ \\
\hline $\begin{array}{l}\text { Protect soil quality during } \\
\text { construction of new landscapes }\end{array}$ & $\begin{array}{l}\text { Determine methods to mitigate } \\
\text { soil compaction; evaluate the } \\
\text { effects of organic soil } \\
\text { amendments }\end{array}$ & Good & $\begin{array}{l}\text { May require expensive } \\
\text { infrastructure or cooperation } \\
\text { of developers/landscape } \\
\text { designers }\end{array}$ \\
\hline $\begin{array}{l}\text { Follow best management practices } \\
\text { (BMPs) (including the Florida } \\
\text { Yards and Neighborhoods } \\
\text { program) }\end{array}$ & $\begin{array}{l}\text { Development and validation of } \\
\text { new (and existing) BMPs at } \\
\text { a residential lot scale }\end{array}$ & Good & $\begin{array}{l}\text { May require high-cost } \\
\text { infrastructure to begin; difficult } \\
\text { to measure success in } \\
\text { "real-world" because } \\
\text { landowners may not follow } \\
\text { protocol correctly }\end{array}$ \\
\hline Use of reclaimed water & $\begin{array}{l}\text { Effects of reclaimed water on } \\
\text { ornamentals; chemical } \\
\text { constituent levels and } \\
\text { variability in reclaimed water }\end{array}$ & Good & $\begin{array}{l}\text { Supply issues and wasted } \\
\text { supply may make it impractical } \\
\text { to provide access to } \\
\text { all landowners }\end{array}$ \\
\hline
\end{tabular}

green industries professionals can have a negative impact on water quality. A U.S. Environmental Protection Agency report estimates that 12\% of the nonpoint pollutant load in the United States originates in urban runoff (U.S. Environmental Protection Agency, 1995). This figure may be higher for Florida as a result of the state's high population density; Florida ranked eighth in the nation with a population density of 296.8 people per square mile in 2000 (U.S. Census Bureau, 2004). Nutrient losses from urban landscapes may be exacerbated in Florida as a result of rainfall, irrigation use, and sandy soils, which tend to promote rapid nutrient leaching.

Relatively few studies have documented the impact of fertilizer or irrigation practices for ornamentals in urban landscapes on water quality. Hipp et al. (1993) evaluated nutrient losses and water use under four mixed landscape (ornamentals and turf) management systems in Texas: 1) Xeriscape $^{\mathrm{TM}}$ — native ornamentals + no irrigation or chemicals; 2) low maintenance-native ornamentals $+\mathrm{N}$ at a rate of $73 \mathrm{~kg} \cdot \mathrm{ha}^{-1}$ per year (two 
applications ) + irrigation at $15 \%$ pan evaporation; 3 ) medium maintenancenonnative grasses and shrubs $+\mathrm{N}$ at a rate of $146 \mathrm{~kg} \cdot \mathrm{ha}^{-1}$ per year (three applications ) + irrigation at $40 \%$ pan evaporation; and 4) high maintenancenonnative grasses and shrubs $+\mathrm{N}$ at a rate of $293 \mathrm{~kg} \cdot \mathrm{ha}^{-1}$ per year (six applications) $+\mathrm{P}$ at a rate of 21 $\mathrm{kg} \cdot \mathrm{ha}^{-1}$ per year $+\mathrm{K}$ at a rate of 36 $\mathrm{kg} \cdot \mathrm{ha}^{-1}$ per year + irrigation at $60 \%$ pan evaporation. Results showed little or no runoff from Xeriscape $\mathrm{T}^{\mathrm{TM}}$ and low maintenance treatments. The highest $\mathrm{N}$ losses were documented from the high-maintenance landscape $\left(1.3 \mathrm{~kg} \cdot \mathrm{ha}^{-1}\right)$. The highest nitrate losses occurred in the first $0.32 \mathrm{~cm}$ runoff immediately after fertilizer application from high-maintenance landscapes. In addition, P losses were significantly higher from landscapes where P was applied.

Studies conducted in Ft. Lauderdale, FL, indicated that N, P, and $\mathrm{K}$ losses from field plots planted with turfgrass monoculture were lower than from field plots planted with mixed ornamental species (Erickson et al., 2001, 2005). However, the fine root weight density (upper $15 \mathrm{~cm}$ ) was much greater with the turf monoculture $\left(467 \mathrm{~g} \cdot \mathrm{m}^{-2}\right)$ than with the mixed landscape $\left(235 \mathrm{~g} \cdot \mathrm{m}^{-2}\right)$. As a result, mixed ornamental landscape leached more N, P, and $\mathrm{K}$ than st. augustinegrass (Stenotaphrum secundatum) during the first year after planting ( $\mathrm{N}$ at 48.3 versus 4.1 $\mathrm{kg} \cdot \mathrm{ha}^{-1}$, respectively). The researchers reported significantly greater leachate volumes from mixed landscapes right after planting than at the end of Year $\mathrm{l}$, suggesting that the amount of $\mathrm{N}$ leached from mixed landscapes may decrease as plants become more established.

\section{Future research needs}

In 2006, the Florida legislature created The Center for Landscape Conservation and Ecology in response to the Green Industry's concern for the long-term sustainability of current landscape management practices. The mission of the Center for Landscape Conservation and Ecology is to protect and preserve Florida's natural resources. University of Florida-IFAS faculty members that are affiliated with the center have been conducting research related to water and nutrient use in Florida's urban landscapes.
Current areas of research for ornamental landscape plants include: fertilizer and water requirements during establishment and maintenance, nutrient and water management for ornamentals in the landscape, and validation of BMPs (Table 4).

According to state and county faculty, there is a definite need for additional research and the resulting educational programs to help homeowners and commercial landscape professionals to better manage water and nutrients in urban landscapes (Tables 5 and 6). Approaches to improve water quality and reduce water use will help to preserve Florida's resources for future generations. It would seem that advocating actions such as fertilizing and watering ornamentals appropriately or using slow- or controlled-release fertilizers would be easy, but much of the fundamental research needed to make the appropriate recommendations has not yet been completed. Also, researchers studying landscape ornamentals often struggle to obtain funding compared with those studying other horticultural crops such as turfgrass and row crops.

\section{Literature cited}

Abrams, M.D., M.E. Kubiske, and K.C. Steiner. 1990. Drought adaptations and responses in five genotypes of Fraxinus pennypanica Marsh: Photosynthesis, water relations and leaf morphology. Tree Physiol. 6:305-315.

American National Standards Institute. 2004. American national standards for tree care operations: Tree, shrub and other woody plant maintenance standards practices (fertilization). Tree Care Ind. Assn, Manchester, NH.

Beverly, R.B., W. Florkowski, and J.M. Ruter. 1997. Fertilizer management by landscape maintenance and lawn care firms in Atlanta. HortTechnology 7:442445 .

Broschat, T.K. 2000. Potassium and phosphorus deficiency symptoms of ixora. HortTechnology 10:314-317.

Broschat, T.K. 2001. Development of an effective fertilization program for palms and other tropical ornamental plants in south Florida landscapes. Res. Rpt. 200101. Univ. Florida Inst. Food Agr. Sci., Fort Lauderdale, FL.

Broschat, T.K. 2005. Nutrient deficiencies of landscape and field-grown palms in Florida. 30 Jan. 2009. <http:// edis.ifas.ufl.edu/document_ep273>.
Broschat, T.K., D.R. Sandrock, M.L. Elliott, and E.F. Gilman. 2008. Effects of fertilizer type and quality and nutrient content of established landscape plants in Florida. HortTechnology 18:278-285.

Cabrera, R.I. and D.R. Devereaux. 1999. Crape myrtle post-transplant growth as affected by nitrogen nutrition during nursery production. J. Amer. Soc. Hort. Sci. 124:94-98.

Cardenas-Laihacar, B., M.D. Dukes, and G.L. Miller. 2008. Sensor-based automation of irrigation on bermudagrass during wet weather conditions. J. Irrig. Drain. Eng. 134:120-128.

Colorado Water Wise Council. 2008. Xeriscape principles. 31 Oct. 2008. <http:// coloradowaterwise.org/index.php? option $=$ com_content\&task=blogcategory \& $\mathrm{id}=72 \&$ Itemid $=245>$.

Costello, L.R. and K.S. Jones. 1998. WUCOLS III: Water use classification of landscape species. 1 May 2008. <http:// www.owue.water.ca.gov/docs/wucols00. pdf>.

Cregg, B.M. 1994. Carbon allocation, gas exchange, and needle morphology of Pinus ponderosa genotypes known to differ in growth and survival under imposed drought. Tree Physiol. 14:883-898.

Denny, G.C., M.A. Arnold, and D.L. Bryan. 2006. Effect of provenance on alkalinity tolerance of baldcypress. HortScience 41:1004(Abstr.).

Denny, G.C., M.A. Arnold, W. Mackay, L. Lombardini, and H.B. Pemberton. 2007. Effect of provenance on drought tolerance of baldcypress. HortScience 42:911(Abstr.).

Dukes, M.D. and D.Z. Haman. 2002. Operation of residential irrigation controllers. 31 Oct. 2008. <http://edis.ifas. ufl.edu/AE221 $>$.

Dukes, M.D., L.E. Trenholm, E.F. Gilman, C.J. Martinez, J.L. Cisar, T.H. Yeager, A.L. Shober, and G.C. Denny. 2008. Frequently asked questions about landscape irrigation for Florida-friendly landscaping ordinances. 30 Jan. 2009. <http:// edis.ifas.ufl.edu/pdffiles/WQ/WQ14200. pdf $>$.

Erickson, J.E., J.L. Cisar, G.H. Snyder, and J.C. Volin. 2005. Phosphorus and potassium leaching under contrasting residential landscape models established on a sandy soil. Crop Sci. 45:546-552.

Erickson, J.E., J.L. Cisar, J.C. Volin, and G.H. Snyder. 2001. Comparing nitrogen runoff and leaching between newly established st. augustinegrass turf and an alternative residential landscape. Crop Sci. 41:1889-1895. 
Ferrini, F. and M. Baietto. 2006. Response to fertilization of different tree species in the urban environment. Arboriculture Urban For. 32:93-99.

Florida Department of Environmental Protection. 2002. Best management practices for protection of water resources in Florida. 30 Apr. 2008. <http://www.dep.state.fl. us/central/Home/MeetingsTraining/ FLGreen/BMP_Book_final.pdf>.

Florida Department of Environmental Protection. 2007.2006 Reuse inventory. 9 May 2008. <http://www.dep.state.fl.us/water/ reuse/docs/inventory/ReuseInventory06. pdf $>$.

Florida Yards and Neighborhoods. 2006. A guide to Florida-friendly landscaping: Florida yards \& neighborhoods program. Univ. Florida Inst. Food Agr. Sci, Gainesville, FL.

Garcia-Navarro, M.C., R.Y. Evans, and R.S. Montserrat. 2004. Estimation of relative water use among ornamental landscape species. Scientia Hort. 99:163174.

Gilman, E.F. 2001. Effect of nursery production method, irrigation, and inoculation with mycorrhizae-forming fungi on establishment of Quercus virginiana. J. Arboriculture 27:30-38.

Gilman, E.F., R.J. Black, and B. Dehgan. 1998. Irrigation volume and frequency and tree size affect establishment rate. J. Arboriculture 24:1-9.

Gilman, E.F., J. Grabosky, A. Stodola, and M.D. Marshall. 2003. Irrigation and container type impact red maple (Acer rubrum L.) 5 years after landscape planting. J. Arboriculture 29:231-236.

Gilman, E.F. and T.H. Yeager. 1990. Fertilizer type and nitrogen rate affects field-grown laurel oak and japanese ligustrum. Proc. Florida State Hort. Soc. 103:370-372.

Gilman, E.F., T.H. Yeager, and D. Kent. 2000. Fertilizer rate and type impacts magnolia and oak growth in sandy landscape soil. J. Arboriculture 26:177-182.

Gilman, E.F., T.H. Yeager, and D. Weigle. 1996. Fertilizer, irrigation, and root ball slicing affects of shrub growth after planting. HortScience 31:605 (Abstr.).

Gregory, J.H., M.D. Dukes, P.H. Jones, and G.L. Miller. 2006. Effect of urban soil compaction on infiltration rate. J. Soil Water Conserv. 61:117-124.

Griffin, J.J., T.G. Ranney, and D.M. Pharr. 2004. Heat and drought influence photosynthesis, water relations, and soluble carbohydrates of two ecotypes of redbud (Cercis canadensis). J. Amer. Soc. Hort. Sci. 129:427-502.
Haley, M.B. and M.D. Dukes. 2007. Evaluation of sensor based residential irrigation water application. Paper No. 072251. Amer. Soc. Agr. Biological Eng., St. Joeseph, MI.

Haley, M.B., M.D. Dukes, and G.L. Miller. 2007. Residential irrigation water use in central Florida. J. Irrig. Drain. Eng. 133:427-434.

Hipp, B., S. Alexander, and T. Knowles. 1993. Use of resource-efficient plants to reduce nitrogen, phosphorus, and pesticide runoff in residential and commercial landscapes. Water Sci. Technol. 28:205-213.

Israel, G.D. and G.W. Knox. 2001. Reaching diverse homeowner audiences with environmental landscape programs: Comparing lawn service users and nonusers. 31 Oct. 2008. <http://edis.ifas.ufl. edu/document_wc044>.

Israel, G.D., J.O. Easton, and G.W. Knox. 1999. Adoption of landscape management practices by Florida residents. HortTechnology 9:262-266.

Israel, G.D., S.B. Pinheiro, and G.W. Knox. 1995. Environmental landscape management: Assessing practices among commercial groups. Univ. Florida Inst. Food Agr. Sci., Gainesville, FL.

Jim, C.Y. 1998. Urban soil characteristics and limitations for landscape planting in Hong Kong. Landsc. Urban Plan. 40: 235-249.

Kidder, G., E.A. Hanlon, T.H. Yeager, and G.L. Miller. 1998. IFAS standardized fertilization recommendations for environmental horticulture crops. 3 May 2008. <http://edis.ifas.ufl.edu/cn01l>.

Knox, G., G. Kidder, E.F. Gilman, L.E. Trenholm, R. Black, T. Wichman, D. Palmer, R. Zerba, C. White, A. Hunsberger, G.D. Israel, J.L. Cisar, K. Ruppert, D. Culbert, C. Kelly-Begazo, S. Park Brown, E. Buss, E. Worden, and C. Vavrina. 2002. Fertilizer recommendations for landscape plants. Univ. Florida Inst. Food Agr. Sci., Gainesville, FL.

Knox, G.W., G.D. Israel, G.L. Davis, R.J. Black, J.M. Schaefer, and S. Park Brown. 1995. Environmental landscape management: Use of practices by Florida consumers. Univ. Florida Inst. Food Agr. Sci., Gainesville, FL.

Law, N., L. Band, and M. Grove. 2004. Nitrogen input from residential lawn care practices in suburban watersheds in Baltimore County, MD. J. Environ. Plann. Manage. 47:737-755.

Levitt, D.G., J.R. Simpson, and J.L. Tipton. 1995. Water use of two landscape tree species in Tucson, Arizona. J. Amer. Soc. Hort. Sci. 120:409-416.
$\mathrm{Li}$, C. 1998. Some aspects of leaf water relations in four provenances of Eucalyptus microtheca seedlings. For. Ecol. Mgt. 111:303-308.

Li, C., F. Berninger, J. Koskela, and E. Sonninen. 2000. Drought response of Eucalyptus microtheca provenances depend on seasonality of rainfall in their place of origin. Aust. J. Plant Physiol. 27:231-238.

Line, D.E., N.M. White, D.L. Osmond, G.D. Jennings, and C.B. Mojonnier. 2002. Pollutant export from various land uses in the upper Neuse River Basin. Water Environ. Res. 74:100-108.

Lipiec, J. and W. Stepniewski. 1995. Effects of soil compaction and tillage systems on uptake and losses of nutrients. Soil Tillage Res. 35:37-52.

Lloyd, J.E., D.A. Herms, M.A. Rose, and J.V. Wagoner. 2006. Fertilization rate and irrigation scheduling in the nursery influence growth, insect performance, and stress tolerance of 'Sutyzam' crabapple in the landscape. HortScience 41:442445 .

Marshall, M.D. and E.F. Gilman. 1997. Production method and irrigation affect root morphology of live oak. J. Environ. Hort. 15:84-87.

Mayer, P.W., W.B. DeOreo, E.M. Optiz, J.C. Kiefer, W.Y. Davis, B. Dziegielewski, and J.O. Nelson. 1999. Residential end uses of water. Amer. Water Works Assn. Res. Foundation, Denver, CO.

Moore, K.A., A.L. Shober, E.F. Gilman, C. Wiese, S.M. Scheiber, M. Paz, and M.M. Brennan. 2009. Posttransplant growth of container-grown wild coffee, copperleaf and orange jasmine is affected by irrigation frequency. Hort Technology 19:789-791.

Mylavarapu, R.S. and E.D. Kennelley. 2002. UF/IFAS Extension Soil Testing Laboratory (ESTL) analytical procedures and training manual. Circulation 1248:19. Univ. Florida Inst. Food Agr. Sci., Gainesville.

Osmond, D.L. and D.H. Hardy. 2004. Characterization of turf practices in five North Carolina communities. J. Environ. Qual. 33:565-575.

Park, D., J.L. Cisar, G.H. Snyder, J. Erickson, S. Daroub, and K. Williams. 2005. Comparison of actual and predicted water budgets from two contrasting residential landscapes in south Florida. Intl. Turfgrass J. 10:885-890.

Perry, E. and G.W. Hickman. 1998. Correlating foliar nitrogen levels with growth in two landscape tree species. J. Arboriculture 24:149-153. 
Rivenshield, A. and N. Bassuk. 2007. Using organic amendments to decrease bulk density and increase macroporosity. Arboriculture Urban For. 33:140-146.

Rose, M.A. 1999. Nutrient use patterns in woody perennials: Implications for increasing fertilizer efficiency in field-grown and landscape ornamentals. HortTechnology 9:613-617.

Rose, M.A. and B. Joyner. 2003. TruGreen Chemlawn research on fertilization of woody ornamentals, p. 121-126. In: A. Siewert, B. Rao, and D. Marion (eds.). Tree and shrub fertilization: Proc. from an international conference on tree and shrub fertilization. Intl. Soc. Arboriculture, Champaign, IL.

Scheiber, S.M., E.F. Gilman, M. Paz, and K.A. Moore. 2007. Irrigation affects landscape establishment of burford holy, pittosporum, and sweet viburnum. HortScience 42:344-348.

Scheiber, S.M., E.F. Gilman, D.R. Sandrock, M. Paz, C. Wiese, and M.M. Brennan. 2008. Postestablishment landscape performance of Florida native and exotic shrubs under irrigated and nonirrigated conditions. HortTechnology 18:59-67.

Shi, Y. and D.H. Byrne. 1995. Tolerance of Prunus rootstocks to potassium carbonate-induced chlorosis. J. Amer. Soc. Hort. Sci. 120:283-285.

Shober, A.L., K.A. Moore, C. Wiese, S.M. Scheiber, E.F. Gilman, M. Paz, M.M. Brennan, and S. Vyapari. 2009. Posttransplant irrigation frequency affects growth of container-grown sweet viburnum in three hardiness zones. HortScience 44:1683-1687.

South Florida Water Management District. 2003. WaterWise: South Florida landscapes. South Florida Water Mgt. District, West Palm Beach, FL.

South Florida Water Management District. 2008. Watering restrictions. 22 Dec. 2008. <http://my.swfwmd.gov/watershortage $>$.

Southwest Florida Water Management District. 2008. Water restrictions. 22 Dec. 2008. <http://www.swfwmd.state. fl.us/conservation/restrictions/>.
St. Hilaire, R. and W.R. Graves. 2001 Stability of provenance differences during development of hard maple seedlings irrigated at two frequencies. HortScience 36:654-657.

St. Johns River Water Management District. 2006. Waterwise Florida landscapes. 29 Jan. 2006. <http://sjrwmd.com/programs/ outreach/conservation/irrigation_rule/ index.html>.

St. Johns River Water Management District. 2008. Drought information and irrigation rule. 22 Dec. 2008. <http:// sjr.state.fl.us/irrigationrule/index.html>.

Struve, D.K. 2002. A review of shade tree nitrogen fertilization research in the United States. J. Arboriculture 28:252263.

Tampa Bay Water. 2005. Evaluating implementation of multiple irrigation and landscape ordinances in the Tampa Bay region. 19 Jan. 2007. <http:// www.tampabaywater.org/conservation/ reportsdocs.aspx>.

Trenholm, L.E., E.F. Gilman, G.W. Knox, and R.J. Black. 2002. Fertilization and irrigation needs for Florida lawns and landscapes. Publ. ENH860. Univ. Florida Inst. Food Agr. Sci., Gainesville, FL.

Tuomela, K. 1997. Leaf water relations in six provenances of Eucalyptus microtheca: A greenhouse experiment. For. Ecol. Mgt. 92:1-10.

U.S. Census Bureau. 2004. Population estimates, Washington, DC. 17 Mar. 2008. <http://www.census.gov/popest/ estimates.php>.

U.S. Environmental Protection Agency. 1995. National water quality: 1994 report to Congress (appendices). U.S. Environmental Protection Agency, Washington, DC.

Valdez-Aguilar, L.A. and D.W. Reed 2006. Comparison of growth and alkalinity-induced responses in two cultivars of hibiscus (Hibiscus rosa-sinensis L.). HortScience 41:1704-1708.

van de Werken, H. 1981. Fertilization and other factors enhancing the growth rate of young shade trees. J. Arboriculture 7:3337

Varlamoff, S., W.J. Florkowski, J.L. Jordan, J. Latimer, and K. Braman. 2001. Georgia homeowner survey of landscape management practices. HortTechnology 11:326331.

Wakida, F.T. and D.N. Lerner. 2006. Potential nitrate leaching to groundwater from house building. Hydrol. Process. 20:2077-2081

Whalley, W.R., E. Dumitru, and A.R. Dexter. 1995. Biological effects of soil compaction. Soil Tillage Res. 35:53-68.

Whitcomb, J.B. 2005. Florida water rates evaluation for single-family homes. 29 Jan. 2006. <http://www.swfwmd.state.fl.us/ documents/reports/water_rate_report. pdf>.

Wichman, T., G. Knox, E.F. Gilman, D.R. Sandrock, B. Schutzman, E. Alvarez, R. Schoellhorn, and B. Larson. 2006. Florida-friendly plant list. Univ. Florida Inst. Food Agr. Sci., Gainesville, FL.

Wiese, C.L., A.L. Shober, E.F. Gilman, M. Paz, K.A. Moore, S.M. Scheiber, M.M. Brennan, and S. Vyapari. 2009. Effects of irrigation frequency during establishment on growth of Illex cornuta 'Burfordii Nana' and Pittosporum tobira 'Variegata'. HortScience 44:1438-1443.

Wood, B.W., L.J. Grauke, and J.A. Payne. 1998. Provenance variation in pecan. J. Amer. Soc. Hort. Sci. 123:1023-1028.

Zahreddine, H.G., D.K. Struve, and S.N. Talhouk. 2007. Growth and nutrient partitioniong of containerized Cercis siliquastrum L. under two fertilizer regimes. Scientia Hort. 112:80-88.

Zollinger, N., R. Kjelgren, T. CernyKoenig, K. Kopp, and R. Koenig. 2006. Drought responses of six ornamental herbaceous perennials. Scientia Hort. 109:267-274.

Zwack, J.A., R.E. Graves, and A.M. Townsend. 1999. Variation among red and Freeman maples in response to drought and flooding. HortScience 34:664-668

Zwack, J.A. and W.R. Graves. 1998. Leaf water relations and plant development of three freeman maple cultivars subjected to drought. J. Amer. Soc. Hort. Sci. 123:371375 . 